\title{
City government and urban inequalities
}

\section{Fran Tonkiss}

What potential do city governments have to prevent and mitigate worsening urban inequalities? Focusing on different urban scales of government, this discussion goes beyond the core tasks of urban service provision to consider strategies of: (i) distribution and deliberation (e.g. revenue measures, living wages or participatory budgeting); (ii) housing and planning (e.g. equity planning, inclusionary zoning, anti-displacement measures, social housing programmes); (iii) environment and infrastructure (e.g. water and waste services, mass transit and non-motorised transport alternatives); and (iv) urban citizenship (e.g. freedom of information, association and movement; public realm and open space strategies).

Key words: urban inequality; cities; urban government; predistribution

The issue of inequality is one of the most pressing in cities today. While it plays out in diverse forms and at stark extremes, inequality is a deepening problem for cities at very different levels of wealth, cutting across any simple distinction between rich and poor world economies. Political efforts to address urban inequalities face two very basic problems of scale. The first concerns the scales at which inequalities are produced. Cities concentrate, make visible and often intensify inequalities which are not, in and of themselves, urban. The disparities in income and wealth that disfigure many cities are driven by geographies of capital that go beyond the urban scale; to regional, national and transnational economies of investment, ownership and control. Similarly, the social inequalities that shape persistent patterns of urban injustice and exclusion - around race, ethnicity, gender, disability, culture, immigration status - are hardly urban in origin or extent. The second problem concerns the scale of effective intervention. Faced with concentrated problems of inequality that are often produced 'elsewhere', urban governments lack the financial and legal capacities, spatial reach, political legitimacy or autonomy to respond with authority or much real impact. They are left to manage the local effects of inequalities over whose wider causes they may have limited power or leverage. 
While recognising these constraints, the discussion that follows makes an argument for the capacities of urban governments to address issues of inequality. This is not to suggest that government is the only - or, often, the primary - domain in which urban inequalities might be tackled. Neither is it to deny the efficacy of non-governmental actors in targeting inequalities in the city. Forms of self-help and mutual aid, cooperative provision and collective action offer critical means of challenging urban disparities. Some of city governments' best ideas, after all, come from the voluntary, community and campaigning sectors. Campaigns for living wages or basic income; struggles against eviction, displacement and enclosure; demands for gender equality; battles for minority and migrant rights; the fight for environmental justice - all continue to be driven by urban activism, social movements and self-organisation. But a focus on city governments seeks to highlight the urban scale, while pushing back against certain orthodoxies of urban governance that have hardened over recent decades. Whether framed in terms of growth machine politics, entrepreneurial governance or more recent modes of austerity urbanism, key tasks of city government have come to be defined by the demands of inward investment, intra-urban competition, marketization and fiscal restraint. On the other side, lack of autonomy, limited capacity and inadequate public budgets underline the challenges urban governments face in any attempt to redress inequalities (see da Cruz et al. 2019).

In face of the politics of state incapacity, abandonment or austerity, it may be too easy to concede that cities bring into high relief current patterns of inequality but lack the means even if they had the will - to alleviate them. It is important to insist, then, on the 'urban effect' at play in the production and reproduction of inequalities. The contemporary organisation of urban economies in diverse regional settings rests on labour and property markets that see increasing wage disparities between high and low-paid workers along with exaggerated returns to capital (see Chen, Liu, and Lu 2018 for urban China; Sarkar 2019 for urban India). Cities spatialize social and economic inequalities in ways that entrench and exacerbate them. Dense urban agglomerations amplify uneven distributions of overconsumption and environmental harms. Given the effectivity of urban environments in embedding and intensifying inequalities, cities are necessarily part of any strategy to address them. My argument here is informed by three propositions. If we recognise, firstly, that urban inequalities are multi-dimensional, then political responses must be multi- 
sectoral. The politics of urban inequality, secondly, is inevitably partisan and frequently conflictual. Both these premises, thirdly, mean that governing urban inequalities involves not only issues of redistribution, but basic conditions of predistribution as well as geographies of social and spatial distribution.

It is conventional, of course, to assert that inequality is (like most problems) multidimensional. It is important to underline this point in urban contexts, however, in expanding the range of strategies potentially in reach of city governments. If municipal authorities have relatively limited control over income disparities and restricted powers of redistribution, they often have more extensive capacities in relation to 'non-income' inequalities around housing, education, environment and health, information and infrastructure, vulnerability and safety, political inclusion and recognition. While income inequality shapes all these forms of disparity, they are not simply reducible to it. One aspect of the 'urban effect' in the production of inequalities is how the sorting of populations and the skewed distribution of urban amenities mean that wealthier residents derive welfare gains in the city relative to their poorer neighbours - easier access, better services, higher quality spaces - which outstrip their nominal income gains (see Couture et al. 2019). Insofar as city governments provide, subsidise or regulate collective goods and services they have powers to offset the consumption cleavages that follow from economic inequality and spatial segregation. Thinking about lived inequities as a problem of government, moreover, means taking seriously the 'existential' inequalities (Therborn 2013) that sustain unequal distributions of respect, recognition and rights between different urban subjects.

Seeing the politics of urban inequality as necessarily partisan - to take up the second proposition - puts into question 'fuzzy' notions of 'inclusive growth' or 'inclusive urbanization', however popular these may be with the OECD and World Bank, or however high they sit on the UN's 'New Urban Agenda' (see Lee 2019, 424-425; UN 2017). These are easy bromides, but they bely the difficulty of the task: governing for inclusion tends to be harder - and more expensive - than going for growth. Indeed, '[f]or government authorities in an urbanizing country, it is easier to try to turn a city into a "growth machine" than an “inclusion machine"' (McGranahan, Schensul, and Singh 2016, 93). The most vital role urban governments play in addressing material conditions of inequality is in ensuring universal 
access to decent basic services, uneven though such provision is across and within urban contexts. Beyond this minimal threshold, the politics of urban inequality is not simply about redressing market failures but about taking on the normal working of markets, as well as the deliberate actions of government at other scales. It is geared to the insistent inequities that organise urban space and order urban social and economic relations; the extent to which the privileged inclusion of certain urban subjects is premised on the systematic exclusion of others from similar types of access, opportunity and amenity. In this sense, the politics of urban inequality is more contentious than the language of inclusive urbanisation would imply. As Edgar Pieterse $(2019,21)$ observes, when conflictual claims, spatial injustice and 'unavoidable trade-offs are obscured it creates a breeding ground for simply perpetuating the status quo irrespective [of] how progressive or radical the planning rhetoric might be. '

Governing urban inequalities, thirdly, involves a politics of predistribution and distribution as much as of redistribution. Urban economies in different development contexts are extensively and increasingly marketised; alongside the deepening disparities to be found in urban labour and housing markets, widening consumption inequalities are driven by the degree to which urban households must meet their broader consumption needs (for energy or water, for transport, for education, health and social care) through markets and the cash economy rather than through public or social provision. This is notably true for the perverse distributions under which the poorest and most precarious urban populations - those living in off-grid informal settlements or under-served peri-urban areas, rural-urban migrant workers - come to pay more for water and fuel, housing and health services than do their better-off neighbours who benefit from public provision, subsidy or regulation (Alabaster 2019; Humanshu 2018; Mitlin, and Walnycki 2020; Ruet et al. 2010; Zhao, Wu, and He 2019). While markets are a primary mechanism for producing inequalities in cities, how extreme and how prevalent such inequalities become, and how far they affect people's wider welfare and life-chances, are questions that cannot simply be settled in market terms. It is necessary to recognise how state policies at different scales have spurred and compounded contemporary urban disparities. Such a stance raises questions of predistribution - the conditions which underlie any system of market distribution or state forms of redistribution. Put simply, a politics of predistribution is alert to the ways that the game has already been rigged. 
Approaches to predistribution have tended to focus on income and wealth inequalities and therefore on measures to address wage or wealth disparities, such as minimum wage, universal basic income or inheritance tax policies. This is based on the view that seeking to manage sharply unequal market outcomes through welfare transfers after the fact does little to change the underlying rules of the game. Faced with widening income and spiralling wealth gaps in contemporary economies, programmes of taxation and redistribution are left running behind an ever-receding horizon of inequality. The argument goes further: income and wealth inequalities are in any case not simply 'market outcomes'; they are effects of the market-shaping actions of government (O'Neill 2020, 78). Given the extent to which neoliberalising governments have intervened in labour, property and financial markets through deregulation and liberalisation, permissive corporate governance regimes or antiunion measures - the field of play has been systematically tilted in the interests of the already more privileged. It is necessary, then, to consider alternative forms of predistribution that might begin to redress the persistent skewing of markets and setting of rules under which wages are determined, income is distributed, and wealth is accumulated and transferred.

Such a politics extends beyond any narrow focus on income redistribution: ' $[t]$ his shift of attention to the broader set of laws and policies that produce inequality aligns with a general broadening of concern with ... the ways in which institutions can either foster or reduce economic inequality. This broader focus could encompass, for example, concerns with minimum wage levels, or the regulation of trade unions and wage bargaining processes, as well as issues of financial and corporate regulation, the regulation of important sectors such as the housing or energy markets, and the use of national and local government procurement spending in shaping the structure of markets.' (O'Neill 2020, 64)

It also includes, I would argue, the terms on which individuals access markets and engage with public and private institutions: anti-discrimination and positive discrimination measures are critical forms of predistribution in aiming to combat market and institutional biases that arbitrarily or systematically disadvantage or exclude members of certain social groups. Urban governments have highly variable legal and taxation powers, but their range 
of potential capacities in respect of planning, procurement, economic development, infrastructure, transport, environment, housing, education, health and social care, political representation and participation open up spaces for 'levelling out' the playing field; shaping the conditions under which resources, space, services, opportunity and voice are distributed in cities.

This last point highlights the very material sense in which the government of urban inequality is concerned with issues of distribution. If distributive justice is generally associated with economic rights and resources, in urban contexts questions of distribution are unavoidably spatial in character. Urban inequalities are not only about who gets how much, but about where they get it. Cities are distributive systems: the processes through which urban populations are sorted in space, resources and risks are dispersed across it, and urban subjects move more or less freely through it, are key domains for thinking about how inequality plays out in spatial terms. In going on, in the next part of the discussion, to consider critical sectors in which city governments might engage with the politics of urban inequality, my focus is largely on measures which seek to redistribute or de-segregate goods, services and amenities across unequal urban spaces, rather than to redistribute or 'de-segregate' populations through - for example - residential mobility or housing subsidy programmes. Such a focus is based on the principle that 'moving resources to people is at least as important as moving people to resources' (Young 1999, 237; see also Sharkey 2016). The right to movement in the city is crucial in both legal and substantive terms - whether in proscribing involuntary segregation or exclusion, promoting basic mobility rights and transport access, or protecting the spatial freedoms of women and minorities. But a politics of spatial justice cannot be premised on the assumption that (some) people are in the wrong place: the city is an exemplary site for thinking about the spatial character of inequalities, and for place-based measures to address them.

In what follows, I outline four spheres in which city governments might address issues of economic, social and spatial inequality. I do not assume regular or robust powers and resources across different urban governments, nor is the aim to provide a comprehensive overview of urban policies and practices. The term 'city government' is necessarily a broad frame: in some cases, particularly in federal systems, metropolitan governments are 
relatively large, empowered and well-resourced, including with effective tax-raising and legislative powers. In other systems, urban government may be devolved to very local levels, with a primary focus on basic service provision. 'Beyond recognizing the importance of sub-national levels of government for reducing many aspects of inequality, generalizations about the role of local governments are not possible. There is too much variation in the structure of governments (from national government to the lowest-level of local government) and in the allocation of responsibilities, roles and resources.' (UCLG 2012, n.p.) Across the $O E C D$, for instance, subnational government revenues (from taxes, grants and subsidies, fees and charges, income from assets, etc) account for more than 40 per cent of all public revenues, but this figure varies widely across countries. Major public investment sectors include economy and transport; education; public service infrastructure; housing and community amenities; and environmental infrastructure, but the order of these priorities and their relative share also diverges across members (OECD 2018). My interest is in spheres of practice and types of intervention that point to the range of potential government capacities and possibilities for urban politics. To this end, the discussion is less concerned with municipal governments as universal service providers than with efforts to respond to inequalities in more contentious sites of urban intervention. It therefore moves beyond the core role of urban government in the provision of basic urban services, health and education to consider the scope for pursuing equity-oriented policies in the areas of: (i) distribution and deliberation; (ii) housing and planning; (iii) environment and infrastructure; and (iv) urban citizenship.

\section{i. Distribution and deliberation}

This first domain of action focuses on the predistributive capacities of urban government. Measures in this sphere include the generation and distribution of urban public revenues, local wage and enterprise policies, public procurement, land value capture and site value taxes, and participatory budgeting. Much of the larger debate over predistribution has highlighted the role of state and national minimum wages in off-setting the power imbalance between employers and low-wage workers in labour markets. While labour organisation continues to be central to the struggle for and setting of minimum wages, the delegitimisation and obstruction of trade union activity in different national contexts, 
declining union densities internationally, and the growing employment share in low-wage and casualised sectors with poor union coverage - together with the inflated costs of living in many cities - mean that public authorities have key roles to play in the campaign for decent wages. In the United States, local minimum wage ordinances have seen dozens of cities require employers to pay minimum wages above those mandated at state or federal levels (see UC Berkeley Center for Labor Research and Education 2020). Similar numbers of US cities have enacted anti-wage theft laws in an effort to combat minimum wage violations, unpaid overtime and tips, illegal deductions, withheld or late payments, and the misclassification of employees as contractors (see Lee and Smith 2019; see also Doussard 2015). In contexts where cities lack the capacity to legislate for local minimum wages, campaigns for a living wage bring together civil society actors, including faith-based organisations and trade unions, with municipal governments and public, private and nonprofit employers to agree and accredit a decent wage floor for low-paid workers (see Linneker and Wills 2016; Parker et al. 2016). Cities, too, provide local test-beds for experiments in universal basic income (Ajuntament de Barcelona 2019).

If city powers may be limited in respect of legislation and enforcement, their role as employers and in public procurement gives urban authorities more direct leverage over wage and workplace standards. Staff costs take the single largest share of subnational public budgets in the OECD, while city and regional governments are responsible for almost half of all public procurement in OECD countries (OECD 2018). The role of municipal governments in public procurement, from capital works to social service provision to the maintenance of their own operations, offers scope for the setting of wage and employment standards, and support for certain kinds of providers, including small-medium local enterprise, cooperatives and social enterprises. Sutton's (2019) study of 'cooperative cities' in the US, for example, analyses a range of metropoles where local ordinances have been passed, procurement policies enacted and investment and incentives geared to the support and development of worker-owned cooperatives (see also Camou 2016). 
In many other urban contexts, the challenges go beyond wage employment and formal enterprises. 'In cities across the world,' as Chen, Roever, and Skinner $(2016,342)$ note, 'households are the major site of production and public space is the major site of exchange. Yet city governments and urban planners do not recognize homes as workplaces or slums and squatter settlements as hubs of production; nor do they recognize street vendors for their contribution to exchange and trade in the city.' Too often, informal workers are subject to the 'punitive arm' of the state but fall outside its 'protective arm'. Chen and her colleagues argue for a fundamental shift in relations between informal workers and urban governments; in another study based on fieldwork in a number of South and Southeast Asian cities - including Ahmedabad, Bangkok and Lahore Chen and Sinha (2016) explore urban policies around housing and informality, basic infrastructure and transport, and land use and zoning as key sites in which municipal governments might protect and promote the economic activities of home-based workers (on street vendors, see Roever 2016; Roever and Skinner 2016).

A further strategy in the politics of predistribution which is particularly relevant to urban governments is the taxation of land and property values. The ownership of public land in cities gives local authorities significant leeway in stewarding the development of affordable housing, equitable social infrastructure and accessible open and public spaces. But in 'many developing cities, the government does not own much land and large-scale acquisition is a political impossibility' (Collier et al. 2018, 2). Capturing rising values through taxes on private land and property offers one alternative, and 'typically represents the largest source of untapped municipal revenue for city authorities.' Land value taxation is progressive in taxing unearned income and wealth (see Kerr 2016) - it would take a pretty hard-core land banker (they do exist, of course) to argue that the increase in land values around a new public transit stop should simply redound to the private owners. While land and property taxes are common across numerous urban contexts - including in Latin America (De Cesare 2012), Africa (Collier et al. 2018; Nyabwengi and K'Akumu 2019) and Asia (Loo 2019) - they have particular relevance in current urban debates around land value capture for funding public development and securing planning gains: i.e. not only as a source of general municipal revenue, but in steering streams of investment towards public goods, including transport, affordable housing, environmental improvements and community infrastructure. 
Thinking about urban revenues in terms of equity has to do not only with the sources of public funding but with decisions over how these revenues are to be spent. Over the last three decades, models of participatory budgeting implemented in the Brazilian city of Porto Alegre have been rolled out in more than 1700 local governments in over 40 countries (Cabannes 2015). These processes of deliberation in which citizens decide how public spending priorities should be set have been taken up in urban contexts with very different local demands, government capacities and public budgets, prompting Yves Cabannes (2015, 267) to ask what might 'a city with an investment capacity of less than one dollar per inhabitant per year (the case in most African municipalities) have in common with those with US\$10,000 per inhabitant per year?' His argument is that participatory budgeting can help to maximise scarce urban resources, directing limited funds towards basic services and social needs in ways that can also lower the time, money and maintenance costs of public works. Calisto Friant (2019), in turn, tracks the shift in priorities over time in Porto Alegre's own participatory budgeting process, from a baseline focus on water, sanitation and street paving in the 1990s to spending on housing and education in the 2000s.

\section{ii. Housing and planning}

In this domain, urban governments draw on tools of equity and advocacy planning, social and public housing provision, rent and tenure stabilisation, anti-gentrification measures, inclusionary zoning, planning obligations and development charges to address the inequalities embedded in housing markets and driven by development processes. 'Given the central role played by changing real estate values and rent levels in the aggregate evolution of capital-income ratios and capital shares in recent decades,' after all, 'it is clear that land use and housing policies have potentially a critical role to play' in responding to widening inequalities (Piketty 2016, 103). Urban property and rents have been key to the blow-out of inequalities in cities, and to a significant extent this has been facilitated by the 'marketshaping' actions of governments, as well as through more explicit policies of urban renewal and development. 
Against the backdrop of state-led gentrification, it is instructive to consider the role urban governments might play in the politics of counter- or anti-gentrification. Writing in the US context, Jeffrey Lubell (2016) outlines an urban governance mix which brings together strategies of regulation, stabilisation, financing, investment and development in order to maintain and expand affordable housing in neighbourhoods where property values are rising. These strategies include: (i) the preservation of affordable housing units through rentrestrictions, housing subsidies and living rent measures; (ii) the protection of existing residents through rent stabilisation and eviction protections, property tax relief or antidisplacement tax funds, rights of return and first refusal for new housing provision; (iii) the inclusion of affordable housing in new developments through inclusionary zoning or planning obligations; (iv) revenue generation from rising local values to fund affordable housing through measures such as land value capture, tax increment financing, development contributions or housing trust funds; ( $v$ ) the creation of incentives for affordable housing development through development subsidies or tax incentives, the transfer of development rights or expedited permitting; and (vi) property acquisition for affordable housing through the assembly of public land, municipal lands banks, in-fill development and densification, property acquisition funds and municipal housing companies (see also Levy, Comey, and Padilla 2006).

Similar strategies can be found in other urban settings. In 2014, the Conseil de Paris expanded the city's droit de préemption urbain (DPU) as part of a broader plan for substantial increases in affordable housing supply. These powers of pre-emption give French municipalities rights of first refusal on the sale of buildings in designated areas. Under its strengthened powers the city has identified some 250 parcels across the city, with a focus on gentrifying areas with populations under pressures of displacement, as pre-emption zones where landlords would be obliged to give the city right of first refusal in the event of a sale (Open Data Paris 2020). In a comparable measure, Berlin has nearly 60 'environment protection areas' (Milieuschutzgebiete), largely in the east of the city, with similar preemption rights and designated with the aim of protecting tenants and retaining the social composition of existing populations. The politics of anti-gentrification and housing equity is an inventive one which draws in legal, planning, tax, regulatory and financing powers in various combinations, often in concert with or led by social and neighbourhood movements 
(see Schöning, Kadi, and Schipper 2017; for resistance to gentrification in Latin American cities, see González 2016; Rodríguez and Di Virgilio 2016; see also Lees 2019; Lees, Annunziata, and Rivas-Alonso 2018; and Granath Hansson 2019 on affordability measures in Swedish and German cities).

\section{iii. Environment and infrastructure}

Environmental inequity and infrastructural exclusions meld material, spatial and vital inequalities in complex ways. This is a domain in which cities often have extensive powers and primary responsibilities: for water, sanitation, waste and recycling; energy provision and local climate policies; food systems and urban agriculture; urban environmental management and regulation; basic and social infrastructures; road networks and public transport; traffic demand management, non-motorised transit and mobility rights.

This sphere of government action ranges from the large and costly to very local, low-cost interventions. To take one of the most basic urban environmental challenges: in their study of solid waste management in 20 cities across six continents, Wilson et al. $(2012,237)$ highlighted both 'the variety and diversity of successful models - there is no 'one size fits all' .... and the need to build on the existing strengths of the city.' This includes 'the critical role of the informal sector in the cities in many developing countries: it not only delivers recycling rates that are comparable with modern Western systems, but also saves the city authorities millions of dollars in avoided waste collection and disposal costs.' In the field of environment and infrastructure, urban governments engage with the politics of distribution in deeply material ways: in the pumping and piping of water; the sorting of waste and delivery of energy; the production and discharge of emissions; the transmission and circulation of environmental harms; the movements of bodies thorough cities. It can be easy to reduce the government of environment and infrastructure to a technocratic realm, a matter of technical systems in common urban environments. But uneven urban geographies of environmental risk, the environmental precarity of the urban poor, problems of fuel poverty and transit inequity in rich world cities, all underline the fact that urban environments are sites of distributive injustice in a very physical sense, built out around spatial infrastructures that shape access, mobility and opportunity in consequential ways. 
This is clear in respect of urban transport and mobility, understood as 'central to actualizing the right to the city' (Pieterse 2019, 32), for spatially and socially marginal populations in particular, and as 'a crucial element of access to socio-economic rights' more generally (Coggin and Pieterse 2017, 303). The 'Corridors of Freedom' programme in Johannesburg is a large-scale strategy that integrates transport and spatial planning with housing and development policy to transform the socio-spatial order of the city (see also Harrison et al. 2019). While these planning precepts are well-known from international models of transitoriented development, the Johannesburg strategy is framed in terms of a reparative politics aiming to 'restitch' a city scarred by the spatial legacies of apartheid, and provide the spatial infrastructure for realising social, economic and political rights in substantive forms (Pieterse 2019, 30). The formal guarantee of rights to representation and participation, education and work, health care and social assistance, information and procedural justice, means relatively little, after all, if you can't physically get to them (see Coggin and Pieterse 2017; see also Gössling 2016).

An equity and rights-based approach to urban transit and development foregrounds the spatial conditions for the politics of equality in the city. It recognises, too, that collective provision can have quite familiar selective outcomes. In recent decades, light rail and bus rapid transit (BRT) networks have been promoted as effective, relatively economical and potentially more sustainable models of mass urban transit, particularly in low and middle income economies. Venter et al. (2018) provide an overview of the equity impacts of BRT systems in African, Asia and Latin America. They suggest that BRT produces real benefits for poorer populations in terms of enhanced spatial access, lower time and money costs, and safety and health impacts. Even so, the benefits of BRT frequently are weighted to middleincome riders and, as such, 'are less progressive than they might be' (140). The privileged consumption of urban amenity by middle and higher income groups is hardly news; Venter et al. $(2018,140)$ argue that transit interventions such as these will only meet 'pro-poor' objectives if they are designed and implemented with 'specific and sustained attention to equity.' This comes back to the observation that the government of urban inequality should be prepared to take partisan positions, to acknowledge disparity and division rather than comfort itself with the palliative politics of inclusion. More inclusive urban planning and 
policies are grounded in the recognition of systematic and structural exclusions, and the barriers which can make it so hard to eliminate them.

\section{iv. Urban citizenship}

A focus on rights brings us to the fourth domain in which to consider the role of city governments in addressing inequalities: that of urban citizenship. The politics of urban citizenship includes freedoms of movement, expression and association; access to information; representation and participation; policing, protection and community safety; public and open space strategies.

The argument that cities provide critical sites for the enactment of substantive rights and social belonging outside the legal framework of national citizenships is well-established in urban and citizenship studies (see, inter alia, Holston and Appadurai 1996; Isin 2007). At the same time, numerous thinkers have traced how formally 'equal' citizenship claims come to be differentiated along lines of property, informality, poverty and migration in contemporary cities (e.g. Bhan 2014; Das 2011; Holston 2011). Meanwhile, cities have become frontiers for the policing of citizenship and the processing of refugees and undocumented migrants by both public and private actors (Varsanyi 2006; Varsanyi 2008; Varsanyi 2011; Darling 2017). Against this background, a progressive politics of urban citizenship is concerned with the protection of rights and dignity across lines of urban disparity and distinctions of formal membership.

Sanctuary, welcoming and solidarity cities in the UK, Europe, North and South America engage with the politics of immigration and citizenship through various strategies. The founding principle of sanctuary cities, particularly in the United States, has been to limit local cooperation with immigration enforcement - to resist that is, the re-scaling of national borders to city level. In these contexts, local public authorities - including police and city officials - refrain from asking about immigration status in their dealings with residents and others, and no legal conditionality should govern access to urban services, including health, education, and indeed policing (see Darling 2017; McDaniel, Rodriguez, and Wang 2019). In other national settings, sanctuary and solidarity movements have been geared more to 
creating positive environments for refugees and asylum seekers, and to programmes of immigrant reception and settlement; from the provision of emergency shelter for undocumented migrants, to the creation of migrant citizenship forums or elected migrant councils for the representation for urban residents who do not have legal voting rights (De Graauw and Vermeulen 2016; Gebhardt 2016; ECCAR 2017; UNESCO 2016; see also Kim, Levin, and Botchwey 2018).

A key precept of the sanctuary movement in the US has been that enforcing national immigration laws is not the responsibility of local governments; they have aimed, that is, to scale back the politico-legal boundaries and obligations of the city. On other fronts, urban governments have sought to devolve to themselves rights instruments and conventions that are more formally the preserve of nation-states. Oomen and Baumgärtel (2018) trace the rise of 'frontier' or 'human rights cities' which have adopted or incorporated human rights codes and covenants, and established municipal human rights agencies for oversight and advocacy (see also Baumgärtel and Oomen 2019). A number of US cities, as they note, 'have adopted the Convention on the Elimination of All Forms of Discrimination against Women as a local ordinance, in spite of the fact that it has not been ratified by the federal government. Similarly, cities in Europe have taken the lead in 'symbolically ratifying' the Convention on the Rights of Persons with Disabilities and implementing its provisions in municipal ordinances, long before the nations concerned followed suit. Another example of a UN treaty taken forward locally is the Convention on the Elimination of All Forms of [...] Racial Discrimination, which forms the basis for the European Coalition of Cities against Racism.' (616-617)

Whether seeking to secede from the legal geography of national immigration enforcement, or to expand the remit of city government to include international human rights treaties, these urban engagements with the politics of migration and citizenship emphasise the 'protective' rather than the 'punitive arm' of the state (to borrow the phrasing of Chen, Roever, and Skinner 2016). At the same time, cities rely on policing functions to secure community safety and redress uneven distributions of vulnerability across differentiated urban populations. The non-cooperation of police departments in sanctuary cities with national immigration enforcement points to wider strategies around urban policing which 
seek to re-balance its punitive and protective functions in diverse and often divided cities. Proximity policing and procedural justice might in this way take its place in a broader urban field of anti-discrimination and anti-exclusionary politics, including - for example - around hate crime and minority community safety (Abanades 2019; Pozzi, De Luca, and Ambrosini 2018), women's safety (Whitzman, Andrew, and Viswanath 2014) and disability rights and access (Pineda, Meyer, and Cruz 2017).

\section{Conclusion}

Inequality is a problem for government. The deepening disparities that characterise many contemporary cities come with economic, environmental and social costs: rationing opportunity and stifling innovation; distributing environmental harms in starkly inequitable fashion; producing social landscapes of fear, conflict, tension and mistrust. But urban governments have highly variable capacities to mitigate, force back or prevent forms of inequality - whether subject to elite capture; in thrall to growth machine or austerity politics; responding to urban inequalities through over-policing or abandonment; or simply lacking in competency, funds or political will. Given the extended geographies across which economic inequalities are produced, and the deep historical legacies of social inequities and exclusions which shape patterns of advantage and exclusion in the city, efforts by urban governments to shift the balance of play and power may at best be compensatory, and at worst of no consequence.

Against such a bleak reading, this discussion has sought to open up ways for thinking about the potential for cities to take progressive action against inequality. Moving beyond the universal provision of basic urban and social services, and the rhetoric of 'inclusive urbanisation', it has focused on sites of inequality and spheres of public intervention that are marked by agonism, competing claims and interests and systematic exclusions. It should not be controversial to assert it is right that urban residents have access to decent, universal urban services. But the argument that property-owners should pay tax on the increasing (and unearned) value of their holdings is likely to be more contentious; as is the suggestion that urban governments might take action on the side of tenants rather than facilitating the operations of developers; or that irregular migrants should have access to urban provision 
and protections irrespective of their legal status. Such a politics recognises that 'local government fundamentally involves the capacity to confront conflictual and irresolvable differences in the city' (Pieterse 2019, 21) - if not always or easily to resolve them. My aim has not been to identify 'best practice' or to talk up demonstration projects for urban policy transfer. The most progressive and most celebrated programmes of city government are always vulnerable to roll-back, retrenchment and the revanchism of electoral cycles (see, for example, Melgar 2014, on Porto Alegre; on Bogotá, see Eaton 2020; Hunt 2017; see also Angotti and Irazábal 2017). Rather it has been to consider different ways of posing problems of urban inequality in different sectors, to pinpoint specific initiatives - some fairly micro, others larger in scope - against an extended range of urban possibilities, initiatives and interventions.

Inequality is a real and present problem that urban citizens and governments may address or ignore, but cannot simply avoid. Efforts to develop city-level strategies are dogged by problems of scale, cause and capacity. The 'urban effect' in contemporary patterns of inequality produces worsening disparities of income and wealth, environmental degradation and injustice, and often stark social divisions and exclusions. Alongside this must be set the potential of cities to support progressive politics of predistribution and redistribution, more collective modes of consumption and deliberation, and more equal distributions of access, recognition and respect. The future of unequal cities may remain undecided, but it is not ungovernable.

\section{References}

Abanades, D. M. 2019. Intercultural Cities Manual on Community Policing. Strasbourg: Council of Europe. https://rm.coe.int/intercultural-cities-manual-on-community-policing /16809390a5.

Ajuntament de Barcelona. 2019. Report on the Preliminary Results of the B-MINCOME Project (2017-2018): Combining a Guaranteed Minimum Income and Active Social Policies in Deprived Urban Areas of Barcelona. Barcelona: Planning and Innovation Department, Area of Social Rights, Barcelona City Council. ajuntament.barcelona.cat/bmincome/en Alabaster, G. 2019. "Cities, Urbanization and Informal Settlements." In The United Nations 
World Water Development Report 2019: Leaving No One Behind, 96-105. Paris: UNESCO. Angotti, T., and C. Irazábal. 2017. "Planning Latin American Cities: Dependencies and "Best Practices"." Latin American Perspectives 44 (2): 4-17.

Baumgärtel, M. and B. Oomen. 2019. “Pulling Human Rights Back In? Local Authorities, International Law and the Reception of Undocumented Migrants." The Journal of Legal Pluralism and Unofficial Law 51 (2): 172-191.

Bhan, G. 2014. "The Impoverishment of Poverty: Reflections on Urban Citizenship and Inequality in Contemporary Delhi." Environment and Urbanization 26 (2): 547-560. Cabannes, Y. 2015. "The Impact of Participatory Budgeting on Basic Services: Municipal Practices and Evidence from the Field." Environment and Urbanization 27 (1): 257-284. Calisto Friant, M. 2019. “Deliberating for Sustainability: Lessons from the Porto Alegre Experiment with Participatory Budgeting." International Journal of Urban Sustainable Development 11 (1): 81-99.

Camou, M. 2016. Cities Developing Worker Co-Ops: Efforts in Ten Cities. Medina, $\mathrm{OH}$ : Imagined Economy Project. www.imaginedeconomy.org Chen, B., D. Liu, and M. Lu. 2018. "City Size, Migration and Urban Inequality in China." China Economic Review 51: 42-58.

Chen, M. A., and S. Sinha. 2016. "Home-based Workers and Cities." Environment and Urbanization 28 (2): 343-358.

Chen, M., S. Roever, and C. Skinner. 2016. “Editorial: Urban Livelihoods: Reframing Theory and Policy." Environment and Urbanization 28 (2): 331-342.

Coggin, T. and M. Pieterse. 2015. “A Right to Transport? Moving Towards a Rights-Based Approach to Mobility in the City." South African Journal on Human Rights 31 (2): 294-314. Collier, P., E. Glaeser, A. Venables, P. Manwaring, and M. Blake. 2018. Land and Property Taxes for Municipal Finance. IGC Cities that Work Policy Paper. https://www.theigc.org/wpcontent/uploads/2017/08/Land-and-Property-Taxes-for-Municipal-Finance-06.07.18.pdf Couture, V., C. Gaubert, J. Handbury, and E. Hurst. 2019. "Income Growth and the Distributional Effects of Urban Spatial Sorting." NBER Working Paper No. 26142. https://www.nber.org/papers/w26142 da Cruz, N. F, P. Rode, and M. McQuarrie. 2019. “New Urban Governance: A Review of Current Themes and Future Priorities." Journal of Urban Affairs 41 (1): 1-19. 
Darling, J. 2017. “Forced Migration and the City: Irregularity, Informality, and the Politics of Presence." Progress in Human Geography 41 (2): 178-198.

Das, V. 2011. "State, Citizenship, and the Urban Poor." Citizenship Studies 15 (3-4): 319-333. De Cesare, C. M. 2012. Improving the Performance of the Property Tax in Latin America. Cambridge, MA: Lincoln Institute of Land Policy.

De Graauw, E., and F. Vermeulen. 2016. "Cities and the Politics of Immigrant Integration: A Comparison of Berlin, Amsterdam, New York City, and San Francisco." Journal of Ethnic and Migration Studies 42 (6): 989-1012.

Doussard, M. 2015. "Equity Planning Outside City Hall: Rescaling Advocacy to Confront the Sources of Urban Problems." Journal of Planning Education and Research 35 (3): 296-306. Eaton, K. 2020. “Bogotá's Left Turn: Counter-neoliberalization in Colombia.” International Journal of Urban and Regional Research 44 (1): 1-17.

ECCAR. 2017. Toolkit for Equality: City Policies Against Racism. Graz, Stockholm and Potsdam: European Coalition of Cities Against Racism.

Gebhardt, D. 2016. "Re-thinking Urban Citizenship for Immigrants from a Policy Perspective: The Case of Barcelona." Citizenship Studies 20 (6-7): 846-866.

González, S. 2016. “Looking Comparatively at Displacement and Resistance to Gentrification in Latin American Cities." Urban Geography 37 (8): 1245-1252.

Gössling, S. 2016. “Urban Transport Justice.” Journal of Transport Geography 54: 1-9. Granath Hansson, A. 2019. "City Strategies for Affordable Housing: The Approaches of Berlin, Hamburg, Stockholm, and Gothenburg." International Journal of Housing Policy 19 (1): 95-119.

Harrison, P., M. Rubin, A., Appelbaum, and R. Dittgen. 2019. “Corridors of Freedom: Analyzing Johannesburg's Ambitious Inclusionary Transit-Oriented Development." Journal of Planning Education and Research 39 (4): 456-468.

Himanshu. 2018. India Inequality Report: Widening Gaps. New Delhi: Oxfam India. https://www.oxfamindia.org/sites/default/files/WideningGaps_IndialnequalityReport2018. pdf.

Holston, J. 2011. “Contesting Privilege with Right: The Transformation of Differentiated Citizenship in Brazil." Citizenship Studies 15 (3-4): 335-352. Holston, J. and A. Appadurai. 1996. "Cities and Citizenship." Public Culture 8 (2): 187-204. 
Hunt, S. L. 2017. “Conflict and Convergence Between Experts and Citizens: Bogotá's TransMilenio." Latin American Perspectives 44 (2): 91-110.

Isin, E. 2007. "City-State: Critique of Scalar Thought." Citizenship Studies 11 (2): 211-28. Kerr, G. 2016. "'Predistribution', Property-owning Democracy and Land Value Taxation." Politics, Philosophy and Economics 15 (1): 67-91.

Kim, A. J., J. M. Levin, and N. D. Botchwey. 2018. "Planning with Unauthorized Immigrant Communities: What Can Cities Do?" Journal of Planning Literature 33 (1): 3-16.

Lee, J. J. and A. Smith. 2019. "Regulating Wage Theft." Washington Law Review 94 (2): $759-$ 822.

Lee, N. 2019. "Inclusive Growth in Cities: A Sympathetic Critique." Regional Studies 53 (3): 424-443.

Lees L. 2019. "Planetary Gentrification and Urban (Re)development." Urban Development Issues 61: 5-13.

Lees, L., S. Annunziata, and C. Rivas-Alonso. 2018. "Resisting Planetary Gentrification: The Value of Survivability in the Fight to Stay Put." Annals of the American Association of Geographers 108 (2): 346-355.

Levy, D. K., J. Comey, and S. Padilla. 2006. Keeping the Neighborhood Affordable: A Handbook of Housing Strategies for Gentrifying Areas. Washington, DC: The Urban Institute. Linneker, B., and J. Wills. 2016. "The London Living Wage and In-Work Poverty Reduction: Impacts on Employers and Workers." Environment and Planning C: Government and Policy 34 (5): 759-776.

Loo, E. M. 2019. "Land Value Capture: The Impossible Tax." IPPR Progressive Review 26 (1): 60-68.

Lubell, J. 2016. “Preserving and Expanding Affordability in Neighborhoods Experiencing Rising Rents and Property Values." Cityscape 18 (3): 131-150.

McDaniel, P. N., D. X. Rodriguez, and Q. Wang. "Immigrant Integration and Receptivity Policy Formation in Welcoming Cities." Journal of Urban Affairs 41 (8): 1142-1166.

McGranahan, G., D. Schensul, and G. Singh. 2016. “Inclusive Urbanization: Can The 2030 Agenda Be Delivered Without It?" Environment and Urbanization 28 (1): 13-34.

Melgar, T. R. 2014. "A Time of Closure? Participatory Budgeting in Porto Alegre, Brazil, after the Workers' Party Era." Journal of Latin American Studies 46 (1): 121-149. 
Mitlin, D. and A. Walnycki. 2020. “Informality as Experimentation: Water Utilities' Strategies for Cost Recovery and their Consequences for Universal Access." The Journal of Development Studies 56 (2): 259-277.

Oomen, B., and M. Baumgärtel. 2018. "Frontier Cities: The Rise of Local Authorities as an Opportunity for International Human Rights Law." European Journal of International Law 29 (2): 607-630.

Nyabwengi, L.M, and O. A. K'Akumu. 2019. “An Evaluation of Property Tax Base in Nairobi City." Journal of Financial Management of Property and Construction 24 (2): 184-199. OECD. 2018. OECD Regions and Cities at a Glance. Paris: OECD.

O’Neill, M. 2020. “Power, Predistribution and Social Justice.” Philosophy 95 (1): 63-91. Open Data Paris. 2020. "PLU - Annexes - Droit de Préemption Urbain Renforcé." Accessed February 20 2020. https://opendata.paris.fr/explore/dataset/plu-annexes-droit-depreemption-urbain-renforce/information/

Parker, J., J. Arrowsmith, R. Fells, and P. Prowse. 2016. “The Living Wage: Concepts, Contexts and Future Concerns." Labour \& Industry: A Journal of the Social and Economic Relations of Work 26 (1): 1-7.

Pieterse, E. 2019. "Urban Governance and Spatial Transformation Ambitions in Johannesburg." Journal of Urban Affairs 41 (1): 20-38.

Piketty, T. 2016. "Capital, Predistribution and Redistribution." In Crooked Timber Seminar on Thomas Piketty's Capital in the Twenty-First Century, edited by Henry Farrell, 90-107. http://crookedtimber.org/wp-content/uploads/2016/01/piketty-final.pdf.

Pineda, V. S., S. Meyer, and J. P. Cruz. 2017. "The Inclusion Imperative: Forging an Inclusive New Urban Agenda." The Journal of Public Space 2 (4): 1-20.

Pozzi, S. D. De Luca, and M. Ambrosini. 2018. Best Practices and Comparative Study: Services, Structures, Strategies and Methodologies on Proximity Policing Against Racism, Xenophobia and Other Forms of Intolerance. Madrid: Ministerio de Trabajo, Migraciones y Seguridad Social.

http://www.mitramiss.gob.es/oberaxe/ficheros/documentos/InformePoliciaProximidad_en. pdf.

Rodríguez, M. C., and M. M. Di Virgilio. 2016. "A City for All? Public Policy and Resistance to Gentrification in the Southern Neighborhoods of Buenos Aires." Urban Geography 37 (8): $1215-1234$ 
Roever, S. 2016. “Informal Trade Meets Informal Governance: Street Vendors and Legal Reform in India, South Africa, and Peru." Cityscape 18 (1): 27-46.

Roever, S., and C. Skinner. 2016. "Street Vendors and Cities." Environment and Urbanization 28 (2): 359-374.

Ruel, M. T., J. L. Garrett, C. Hawkes, and M. J. Cohen. 2010. “The Food, Fuel, and Financial Crises Affect the Urban and Rural Poor Disproportionately: A Review of the Evidence." The Journal of Nutrition 140 (1): 170S-176S. https://doi.org/10.3945/jn.109.110791.

Sarkar, S. 2019. "Employment Change in Occupations in Urban India: Implications for Wage Inequality." Development and Change 50 (5): 1398-1429.

Schöning, B, J. Kadi, S. Schipper (eds.). 2017. Wohnraum für alle?! Perspektiven auf Planung, Politik und Architektur. Bielefeld: transcript.

Sharkey, P. 2016. "Neighborhoods, Cities, and Economic Mobility." RSF: The Russell Sage Foundation Journal of the Social Sciences 2 (2): 159-177.

Sutton, S. A. 2019. “Cooperative Cities: Municipal Support for Worker Cooperatives in the United States." Journal of Urban Affairs 41 (8): 1081-1102.

Therborn, G. 2013. The Killing Fields of Inequality. Cambridge: Polity.

UC Berkeley Center for Labor Research and Education. 2020. Inventory of Local Minimum Wage Ordinances (Cities and Counties). [last updated, 13 February 2020]. http://laborcenter.berkeley.edu/minimum-wage-living-wage-resources/inventory-of-uscity-and-county-minimum-wage-ordinances/

UCLG. 2012. "Who Can Address Urban Inequality? The Often Forgotten Roles of Local Government." Barcelona: United Cities and Local Government.

www.uclg.org./en/issues/global-taskforce.

UN. 2017. New Urban Agenda. New York: United Nations.

UNESCO. 2016. Cities Welcoming Refugees and Migrants: Enhancing Effective Urban Governance in an Age of Migration. Paris: UNESCO.

Varsanyi, M. W. 2006. “Interrogating 'Urban Citizenship’ vis-à-vis Undocumented Migration." Citizenship Studies 10 (2): 229-249.

Varsanyi, M. W. 2008. "Immigration Policing Through the Backdoor: City Ordinances, the 'Right to the City,' and the Exclusion of Undocumented Day Laborers." Urban Geography 29 (1): 29-52.

Varsanyi, M.W. 2011. “Neoliberalism and Nativism: Local Anti-Immigrant Policy Activism and 
an Emerging Politics of Scale." International Journal of Urban and Regional Research 35 (2): 295-311.

Venter, C., G. Jennings, D. Hidalgo, and A. F. Valderrama Pineda. 2018. “The Equity Impacts of Bus Rapid Transit: A Review of the Evidence and Implications for Sustainable Transport." International Journal of Sustainable Transportation 12 (2): 140-152. Whitzman, C., C. Andrew, and K. Viswanath. 2014. "Partnerships for Women's Safety in the City: 'Four Legs for a Good Table'.” Environment \& Urbanization 26 (2): 443-456.

Wilson, D. C., L. Rodic, A. Scheinberg, C. A. Velis, and G. Alabaster. 2012. “Comparative Analysis of Solid Waste Management in 20 Cities." Waste Management \& Research 30 (3): 237-254.

Young, I. M. 1999. “Residential Segregation and Differentiated Citizenship." Citizenship Studies 3 (2): 237-252.

Zhao, D. T. Wu, and Q. He. 2017. “Consumption Inequality and its Evolution in Urban China', China Economic Review 46: 208-228.

Fran Tonkiss is in the Department of Sociology at the London School of Economics. Email: f.tonkiss@Ise.ac.uk 